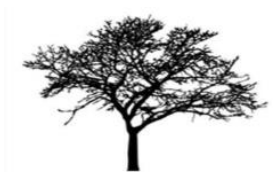

AVRASYA Uluslararası Araştırmalar Dergisi

Cilt : 6 Sayı : 13 Sayfa: 382 - 397 Mayıs 2018 Türkiye

\title{
ALMANCA VE TÜRKÇE ÖLÜM İLANLARINDAKI ÖRTMECE SÖZLERDE ÖLÜM ALGISI
}

Dr. Öğr. Üye. Hasan Kazım KALKAN*

\begin{abstract}
Öz
Örtmece sözler herhangi bir kavramın anlamını değiştirmeden, yalnızca o kavramı ifade eden dilsel göstergelerin değiştirilmesiyle yapılan dil oyunlarıdır. Amaç anlamı değil, anlamın yarattığı olumsuz etkiyi değiştirmek ya da katlanılabilir hâle getirmektir. Herhangi bir kavramın ya da olayın güzelleştirilerek anlatılması anlamına gelen örtmeceler, Türkçede "iyi adlandırma, edeb-i kelâm, hüsn-i tabir" gibi kelimelerle, Almancada ise "Euphemismus" şeklinde ifade edilir. Örtmece sözler bir yandan dilin ve edebiyatın zenginleşmesine katkı sağlarken, diğer yandan da toplumların herhangi bir olayı nasıl algıladıklarının önemli göstergelerinden bir tanesi olarak psikoloji, sosyoloji ve halk bilimi gibi bilim dalları içinde önemli veriler sunarlar. Çünkü toplumların kelimelere yüklemiş oldukları anlam, aynı zamanda onların nesneleri ya da olayları nasıl algıladıklarının da bir göstergesidir. Bu açıdan bakıldığında ölüm yerine kullanılan örtmece sözlerin toplumların ölüm algısına dair önemli ipuçları vereceği düşünülebilir. Ölüm her insanın mutlaka yüzleşmek zorunda kaldığı bir olgudur ve her ne kadar vaka olarak evrensel kültürün parçası olsa da, algılanma biçimi itibarıyla yerel kültürün bir parçasıdır. Bu çalışmayla Türk ve Alman toplumlarındaki ölüm algısının gazetelerin ölüm ilanlarında yer alan örtmeceler üzerinden analiz edilmesi hedeflenmiştir. Bu amaçla Türkiye ve Almanya'dan günlük satış rakamları birbirine çok yakın iki gazete seçilmiş ve 15-30 Ağustos 2017 tarihleri arasında söz konusu gazetelerde yayınlanan ölüm ilanları mercek altına alınmıştır. Araştırmanın birinci aşamasında örtmeceler tespit edilerek kullanım sıklıkları hesaplanmış ve ölümü algılayış biçimleri esas alınarak belli sınıflandırmalar yapılmıştır. İkinci aşamada ise elde edilen veriler karşılaştırmalı betimlemeli yöntemle yorumlanmıştır.
\end{abstract}

\section{Anahtar Kelimeler: Örtmece, Ölüm Algısı, Karşılaştırmalı Edebiyat \\ DEATH PERCEPTION IN EUPHEMISMS IN GERMAN AND TURKISH DEATH ANNOUNCEMENTS}

\section{ABSTRACT}

Euphemisms are language games made by changing the linguistic indications expressing only a concept without changing the meaning of that concept. The goal is not changing the meaning, but to change the negative effect that the meaning has created or to make it bearable. Euphemizations meaning to narrate a concept or event by beautifying it, are expressed with the words such as "iyi adlandırma (good naming), edeb-i kelam (euphemism), hüsn-i tabir (euphemism) in Turkish and as "euphemismus (euphemism) in German. While euphemized words contribute to the richness of the language and the literature, they also offer important data for sciences such as psychology, sociology and folklore as one of the important indications of how the societies perceive any event. Because the meaning the societies ascribed to the words is also an indication of how they perceive the objects or events. From this point of view, it can be considered that the euphemized words used in place of death may provide important clues to the perception of death by societies. Death is a fact that surely every human being must confront, and even though as part of universal culture as a case, it is part of the local culture with regards to its form of being perceived. With this study, it was aimed to analyze the perception of death in the Turkish and German societies over the euphemizations in the death announcements of the newspapers. With this purpose, two newspapers from Turkey and Germany with very similar daily sales figures were chosen and death announcements published in the subject newspapers between the dates 15-30 August 2017 were scrutinized. In the first stage of the study, the euphemizations were determined, and their frequency of use was calculated, and certain classifications were made based on the forms of death perception. In the second stage, the obtained data were interpreted with comparative descriptive method.

Keywords: Euphemism, Perception of Death, Comparative Literature

“ Öğr. Gör. Dr. Hasan Kazım KALKAN, Gazi Eğitim Fakültesi, Alman Dili Eğitimi Anabilim Dalı 



\section{Giriş}

Ölüm olgusu insanoğlunun yaşamak zorunda olduğu temel hayat deneyimlerinin en başta gelenlerindendir. İster Afrika ormanlarının hâlâ ilkel hayat yaşayan bir topluluğuna, isterse Batı medeniyetinin en gelişmiş milletine mensup olsun, her insan mutlaka ölüm gerçeği ile yüzleşmek zorundadır. Bu durum, ölüm temasını edebiyat sanatının çok sık kullandığı malzemelerden biri hâline getirmiştir. Fakat ölümün genellikle çok arzu edilmeyen, hatta korkulan bir olay olması, güzelleştirerek anlatmak şeklinde açıklayabileceğimiz örtmece sözlerin ölüm bağlamında hem çeşitlenmesi, hem de sık kullanılmasına yol açmıştır. Böylelikle örtmece sözler bir yandan dilin ve edebiyatı zenginleşmesine katkı sağlayan önemli unsurlar olmuş, diğer yandan da toplumların herhangi bir olayı nasıl algıladıklarının önemli göstergelerinden birisi olarak psikoloji, sosyoloji ve halk bilimi gibi bilim dalları için önemli veri kaynakları hâline gelmiştir. İnsanoğlunun kelimelere yüklemiş olduğu anlamların aynı zamanda onun hayat algısını da yansıttığını göz önünde bulundurursak, ölüm üzerine söylenmiş örtmece sözlerin, milletlerin ölüm algılarını tespit etme noktasında kayda değer bilgiler sunabileceği düşünülebilir. Çünkü ölüm her insanın mutlaka yüzleşmek zorunda kaldığı bir olgudur ve her ne kadar vaka olarak evrensel kültürün bir parçası olsa da, algılanma biçimi itibarıyla yerel kültürün bir yansımasıdır.

\section{Yöntem}

Bu çalışmayla ölüm hakkındaki örtmece sözlerin Türk ve Alman gazetelerindeki ölüm ilanlarına nasıl yansıdığının incelenmesi hedeflenmiştir. İncelemeye tabi tutulacak metinler Türkiye'nin en çok satan gazetesi Hürriyet ${ }^{1}$ ve Almanya'nın en çok satan ikinci gazetesi Süddeutsche Zeitung'dan ${ }^{2}$ seçilmiştir. Günlük satış rakamlarının birbirine yakınlığı söz konusu gazetelerin seçilmesindeki temel etkeni oluşturmuştur. Ayrıca her iki gazetenin saygınlık bakımından (her ne kadar göreceli olsa da) ülkelerinin en önemlileri arasında yer alması yaptığımız tercihi pekiştiren faktörlerden olmuştur. Bu iki gazetede iki hafta boyunca (15-30 Ağustos 2017) yayınlanmış olan ölüm ilanları taranarak tespit edilmiş, karşılaştırmalı betimlemeli yöntemle eş zamanlı olarak incelenmiştir. Ayrıca 2000 yılında hazırlanan ve bu çalışmayla benzeşen bir doktora tezi sayesinde art zamanlı inceleme yapma fırsatından da istifade edilmiştir.

\section{1. Örtmece Sözler}

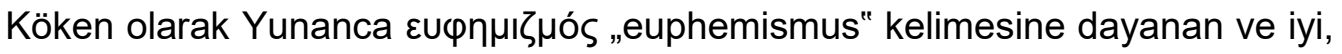
uğurlu söz söyleme" anlamı taşıyan (Aksan 1998: 98) örtmece kavramı, Türk Dil Kurumu Sözlüğü'nde "Söylenmesi kaba, çirkin veya sakıncalı görülen nesnelerin, kavramların, başka kelimelerle daha uygun ve edepli bir biçimde anlatılması,

\footnotetext{
${ }^{1}$ Söz konusu tarihlerde Hürriyet gazetesinin günlük baskı sayısı ortalama 315 bin civarındadır. (Gazete tirajları, 2017)

2 Almanya'nın en çok okunan gazetesi günlük ortalama 2,5 milyonluk baskıya sahip Bild'dir. Fakat bir bulvar gazetesi olması ve toplumun eğitimli kesimlerince ciddiye alınmaması nedeniyle Hürriyet gazetesinin Almanya'daki muadili olarak görülebilmesi mümkün olmadığından Süddeutsche Zeitung'da karar kılınmıştır. (Bild Gazetesi ile ilgili yorumumuz tamamen öznel olup tartışmaya açıktır). Süddeutsche Zeitung'un Ağustos 2017 ortalama baskı sayısı 350.104'dür. (STATISTA, 2017)
} 
edebikelam" (TDK 2017) olarak tanımlanmıştır. Doğan Aksan ise örtmece yerine "güzel adlandırma" ifadesini kullanmış ve ilgili terimi "Kimi varlıklardan, nesnelerden söz edildiğinde doğacak korku, ürkme, iğrenme gibi duyguların, kötü izlenim ve çağrışımların önlenmesi amacına yönelen ve dünyanın her dilinde rastlanan bir değiştirme olayı" (Aksan 2009: 98) şeklinde nitelemiştir. Bununla birlikte örtmeceyi "edebi kelam, güzelleme, hüsnü tabir" (Bilginer 2001: 441), "mümtaziyet" (Mevlevi 1984: 40) şeklinde adlandıran kaynaklar da mevcuttur. Örtmece sözlerin Alman edebiyatındaki karşılığı ise "Euphemismus"tur. Euphemismus Almanca sözlük Duden'de, "yakışıksız ve hoş olmayan bir kelime için (kullanılan) güzelleştirici, perdeleyici, yumuşatıcı dolaylı ifade" (Duden 1996: 467) şeklinde açıklanmaktadır. Alman edebiyatının terimsel sözlüğünde ise "utanma duygusu, terbiye, dinî çekinceler veya batıl inançlardan dolayı; hoş olmayan, yakışıksız ya da uğursuzluk getiren bir durumu, tehlikeli sonuçlar doğuran kelimelerden kaçınmak amacıyla, yumuşatarak veya güzelleştirerek ifade eden perdeleyici dolaylı ifade" (von Wilpert 1989: 270) şeklinde yer almaktadır. Örtmece sözler herhangi bir kavramın anlamını değiştirmeden, yalnızca o kavramı ifade eden dilsel göstergelerin değiştirilmesiyle yapılan dil oyunlarıdır. Amaç anlamı değil, anlamın yarattığı olumsuz etkiyi değiştirmek ya da katlanılabilir hâle getirmektir. Nitekim Zöllner'e (1997: 109) göre de; psikolojik açıdan gözlemlendiğinde, örtmece bir ifade ve yerine kullanılmış olduğu kavram, aynı dil dışı gerçekliği ifade etseler bile, aynı derecede negatif etkiyi yaratmamaktadırlar. Bu yüzden örtmecelerin tek başına dilsel bir olgu olarak değil, aksine sosyo-kültürel arka plan da dikkate alınarak incelenmesi gerekir.

Örtmece sözleri doğuran ve toplumda kabul görmesine sebebiyet veren en önemli etkenlerin başında tabular gelir. Luchtenberg'e (1985: 24) göre tabu; düşünme, dokunma ve adını anma yasaklarıyla nesneler, olaylar ve düşüncelerin yasaklanmasıdır. Dilsel Tabular ise "Hoş karşılanmayan, sevilmeyen ya da korkulan şeylerin adının anılmaması, aksi takdirde o şeyin insanı rahatsız edeceği inancı" (Duman 2012: 100) ile ortaya çıkarlar. Tabular kararlaştırılmış, gerekçelendirilmiş, öğretilmiş ve yazıya dökülmüş değildirler. Uzun ve ortak bir tecrübe sürecinin sonunda oluşurlar (Türcke 1994). Usubaliyev'e (1995) göre örtmece sözler tabu kaynaklı olabildiği gibi ahlaki değer ve nezaket kurallarına dayalı sakınmaların neticesi olarak da ortaya çıkabilirler (Güngör 2006: 80-81). Herhangi bir dilsel göstergenin tabuya dönüşmesi, o göstergenin nitelediği olgunun toplum hayatından çıkarılması anlamına gelmemektedir. Aksine söz konusu olgu yine eski canlılığıyla, fakat başka bir ada bürünerek yaşamaya devam etmektedir. Tabular söz konusu olduğunda "kaçınma" (tabu kelimelerden) stratejisi devreye girmekte ve üzeri örtülü kelimelerin kullanımıyla hedef gerçekleştirilmektedir (Rammstedt 1964: 41). Schröder (2013) ise aynı durumu "iletişim için yedek araçların kullanıma sokulması" olarak tarif etmektedir. Kaçınma stratejilerinin uygulanmasını mümkün kılan dilsel ögeler içerisinde örtmeceler oldukça önemli bir yere sahiptir. Örtmeceler dile ifade zenginliği katan ve güzelleştiren unsurlar olmakla birlikte, ası önemli katkılarını iki temel alanda sunarlar: Birincisi, örtmece kelimeler, dilsel tabuların oluşumuna neden olan nesneleri, olayları ya da düşünceleri ifade eden kavramların, başka bir forma bürünerek dildeki varlıklarını devam ettirebilmelerinde büyük rol oynarlar. İkincisi ise, örtmece ifadelerin sağlamış olduğu imkânlar sayesinde, tabu kelimelerin kullanılmamasından dolayı yaşanması muhtemel 
iletişim aksaklıklarının önüne geçilir. Bir kavramı ifade eden örtmecelerin sayısı, kavramın toplum hayatındaki kullanım sıklığı ve yarattığı algının derecesi ile doğru orantılıdır. Ölümün, ne zaman nereden geleceği belli olmayan ve bilinmezliğiyle insana korku veren bir vaka olması, hem Türkçede ${ }^{3}$ hem de Almancada ${ }^{4}$ ölümle ilgili çok sayıda örtmece ifadenin ortaya çıkmasına yol açmıştır.

\section{2. Ölüm lanlarında Örtmece Kullanım Oranı}

Çalışmanın bu bölümünde Türkçe ve Almanca ölüm ilanlarında örtmece kullanım oranı değişik boyutlarıyla tespit edilecektir.

\begin{tabular}{lllll}
\hline \multicolumn{3}{l}{ Almanca } & Türkçe \\
\hline & Sayı & & Sayı \\
Örtmece kullanılan & 95 & 74 & 180 & 99 \\
Örtmece kullanılmayan & 34 & 26 & 2 & 1 \\
& & & & \\
Toplam & 29 & 100 & 182 & 100 \\
\hline
\end{tabular}

Tablo 1: Ölüm İlanlarında Örtmece Kullanım Oranı

Tablo 1'de görüldüğü üzere Süddeutsche Zeitung adlı gazetede toplam 129 tane ölüm ilanından 95 tanesinde örtmece sözler kullanılmış, 34 tanesinde ise kullanılmamıştır. Bu da \%74'lük bir orana tekabül etmektedir. Örtmeceye yer verilmeyen ilanlarda ise, İncil'den bölümler, özlü sözler, şiirler kullanılmış ya da dolaylı veya direk olarak ölüme hiçbir göndermede bulunmayan metinler kullanılmıştır. Hürriyet gazetesinde yer alan Türkçe 182 ölüm ilanının 180 tanesinde örtmece, diğer iki tanesinde ise şiir kullanılmıştır. Bu verilere göre Türkçedeki örtmece kullanım oranı neredeyse \%100'e yakındır. Çeşitlilik açısından bakıldığında ise Almanca metinlerin Türkçedekilere kıyasla daha zengin olduğu görülmektedir. Almancada toplam 13 farklı örtmece ifade kullanılmışken Türkçe ilanlarda bu rakam 9'dur.

\subsection{Tüzel Kişiliklerin İlanlarında Örtmece Kullanımı}

\footnotetext{
${ }^{3}$ Türkçede kullanılan örtmecelerden bazıları: emrihak vaki olmak, ahiret yolcusu olmak, ecel şerbetini içmek, günü dolmak, ömrü vefa etmemek, ömür defterini kapatmak, vadesi dolmak, adres değiştirmek, ahrete intikal etmek, dünyasını değiştirmek, dar-1 bekaya irtihal etmek, dünyaya veda temek, ebediyete göçmek, can borcunu ödemek, ruhunu teslim etmek, dünyaya gözlerini yummak, Hakk'a yürümek, rahmet-i rahmana kavuşmak, sonsuzluğa intikal etmek, ruhunu teslim eylemek, son nefesini vermek, vefat etmek, yaşamını yitirmek/kaybetmek. (Türkmen 2009: 134)

${ }^{4}$ Almancada kullanılan örtmecelerden bazıları: (die) Augen für immer schließen, ableben, das Zeitliche segnen, davongehen, entschlafen, gehen, in den letzten Zügen liegen, in die ewigen Jagdgründe eingehen, (jemandes) letztes Stündlein hat geschlagen, (die) Reihen lichten sich, sanft entschlafen, (jemandem) schlägt die Stunde, sein Leben aushauchen, sein Leben lassen, seinen Geist aushauchen, seinen letzten Gang gehen, uns verlassen versterben, von der Bühne des Lebens abtreten, von uns gehen, dahingehen, vor seinen Richter treten, vor seinen Schöpfer treten, (den) Weg allen Fleisches gehen, dahingerafft werden, den Geist aufgeben, (seine) letzte Fahrt antreten, seinen Geist aufgeben.
} 
İncelenen gazetelerde tüzel kişiliklere ait ölüm ilanları da önemli bir yer tutmaktadır. Tüzel kişiliklerin örtmece kullanım sıklığının saptanması amacıyla Tablo 2 hazırlanmıştır.

\begin{tabular}{llll}
\hline & $\begin{array}{l}\text { Toplam } \\
\text { ilan sayısı }\end{array}$ & $\begin{array}{l}\text { Örtmeceli } \\
\text { ilan sayısı }\end{array}$ & \\
\hline Almanca & 41 & 38 & 93 \\
Türkçe & 97 & 97 & 100
\end{tabular}

Tablo 2: Tüzel Kişiliklerin Örtmece Kullanımı

Tüzel kişilikler üzerinden bakıldığında her iki dilde de örtmece kullanım oranının oldukça yüksek olduğu görülmektedir. Türkçede $\% 100$ olan bu oran, Almancada \% 93 civarında seyretmektedir. Söz konusu rakamlar karşılaştırıldığında, Türk tüzel kişiliklerinin ölüm ilanlarında örtmece kullanma oranının Alman tüzel kişiliklerine göre biraz daha fazla olduğu söylenebilir.

\section{2. Ölüm İlanlarında Kullanılan Örtmece Sözler}

Belirlenen gazetelerin ölüm ilanlarındaki örtmeceler, kullanım sıklıkları ile birlikte aşağıdaki tablolarda oransal olarak gösterilmişlerdir.

\begin{tabular}{|c|c|}
\hline Almanca Örtmeceler & $\begin{array}{l}\text { Kullanım } \\
\text { Oranı (\%) }\end{array}$ \\
\hline $\begin{array}{l}\text { Abschied nehmen von } \\
\text { (veda etmek) }\end{array}$ & 37 \\
\hline $\begin{array}{l}\text { Daheim einschlafen } \\
\text { (evinde uykuya dalmak) }\end{array}$ & 2 \\
\hline $\begin{array}{l}\text { Das Leben verlassen } \\
\text { (hayatını kaybetmek) }\end{array}$ & 1 \\
\hline $\begin{array}{l}\text { Heimgehen } \\
\text { (eve gitmek) }\end{array}$ & 1 \\
\hline $\begin{array}{l}\text { Im Himmel sein } \\
\text { (cennette olmak) }\end{array}$ & 1 \\
\hline $\begin{array}{c}\text { In Herzen weiterleben } \\
\text { (kalplerde yaşamaya devam etmek) }\end{array}$ & 2 \\
\hline $\begin{array}{l}\text { Trauern um jmdn } \\
\text { (yasını tutmak) }\end{array}$ & 35 \\
\hline
\end{tabular}




\begin{tabular}{|c|c|c|}
\hline & $\begin{array}{l}\text { (Jemanden) verlassen } \\
\text { (birisinden ayrılmak) }\end{array}$ & 4 \\
\hline & $\begin{array}{l}\text { Versterben } \\
\text { (vefat etmek) }\end{array}$ & 13 \\
\hline werden & Von Christus gerufen & 1 \\
\hline & (İsa tarafından çağrılmak) & \\
\hline & $\begin{array}{l}\text { Von (uns) gegangen } \\
\text { (birisinden ayrılmak/gitmek) }\end{array}$ & 1 \\
\hline & $\begin{array}{l}\text { Voraus gehen } \\
\text { (önden gitmek) }\end{array}$ & 1 \\
\hline erwache & $\begin{array}{l}\text { Zum ewigen Leben } \\
\text { n }\end{array}$ & 1 \\
\hline & (ebedi hayata uyanmak) & \\
\hline & Toplam & 100 \\
\hline
\end{tabular}

Tablo 3: Almanca Örtmeceler ve Sıklık Oranları

\begin{tabular}{cl}
\hline Türkçe Örtmeceler & $\begin{array}{l}\text { Kullanım } \\
\text { Oranı (\%) }\end{array}$ \\
Aramızdan ayrıımak & 1 \\
Ebedi istirahatgahına & 1 \\
Ebediyete intikal etmek & 1 \\
Ebediyete uğurlamak & 1 \\
Hakkın rahmetine & 19 \\
Kavuşmaketmek & 45 \\
Seyahate çıkmak & 1 \\
Vefat etmek & 30 \\
Yitirmek & 1 \\
\hline Toplam & 100 \\
\hline
\end{tabular}


Tablo 4: Türkçe Örtmeceler ve Sıklık Oranları

Tabloda görüldüğü üzere Almanca ölüm ilanlarında en çok kullanılan dört ifade neredeyse tüm örtmece sözlerin \%90'ını oluşturmaktadır. İlk sırayı \%35 ile "Abschied nehmen von..." almakta, ikinci sırada \%35 ile "trauern um jemanden" gelmektetir. Bunları \%13 ile "versterben" ve \%4 ile "verlassen" takip etmektedir. Diğerlerinin kullanım oranları \%1-2 seviyesindedir. Benzer bir durum Türkçe metinler için de söz konusudur: en sık yer verilen üç örtmecenin toplamdaki oranı \%94'e tekabül etmektedir. Geride kalanların kullanım sıklıkları ise $\% 1$ civarındadır. Türkçe ölüm ilanlarında en sık kullanılan üç örtmecenin sırasıyla; "Kaybetmek, Hakkın rahmetine kavuşmak ve vefat etmek" olduğu görülmektedir.

\section{Dinî Motifli Örtmeceler}

Insanoğlunun öldükten sonra başka bir boyutta yaşamaya devam edeceği düşüncesi Türk (Yeşil 2014) ve dünya milletlerinde ilkçağlardan günümüze kadar birçok inanç sisteminde işlenmiştir. Almanların ataları olarak bilinen Cermenlerin inanç sisteminde de ölümden sonraki hayat önemli bir yer tutar. Bu inanışa göre çarpışmalarda ölen savaşçılar baba tanrı Odin tarafından Walhalla'da karşılanır ve ağırlanırlar (Braun 1996: 176). Yaşlılık veya hastalık nedeniyle hayatını kaybedenler ise "Hel" adı verilen yer altındaki ölüler diyarında tekrar bir araya toplanarak yaşamaya devam ederler (Maier 2003: 85). Cermen boylarının Hristiyanlaşma sürecinden sonra da ölümden sonraki hayata olan inanış yeni dinin inanç formlarını alarak devam etmiştir. Hristiyanlıkta da ölümden sonraki yeniden diriliş inancı son derece mühimdir ve Hristiyanlığın kutsal kitabı İncil'de buna gönderme yapan birçok ayet mevcuttur. (bk. Selanikliler $4 / 16^{5}$, Yuhanna $5 / 29^{6}$, Yeşaya $26 / 19^{7}$ ). "Tarihî açıdan bakıldığında hem diriliş hem de ruhun ölümsüzlüğü inancı tarih boyunca Hristiyan teolojisinde yer almıştır" (Akbaş 2002: 55). Nitekim Tablo 5 incelendiğinde de milletlerin inanç sistemlerinin yansımalarını görmek mümkündür. Söz konusu tabloda, kaynağını Hristiyanlıktan alan dinî motifli örtmeceler seçilerek yeni bir sınıflandırmaya gidildiğinde aşağıdaki tablo oluşmaktadır:

\begin{tabular}{c}
\hline Almanca \\
\hline Die Welt/jemanden verlassen \\
Heimgehen \\
Im Himmel sein \\
Von Christus gerufen werden \\
Voraus gehen
\end{tabular}

\footnotetext{
${ }^{5}$ Rab'bin kendisi, başmeleğin ve Tanrı'nın borazan sesiyle gökten inecek ve önce Mesih’e ait ölüler dirilecek.

${ }^{6}$ İyilik yapmış olanlar yaşamak, kötülük yapmış olanlar yargılanmak üzere dirilecekler.

${ }^{7}$ Ama senin ölülerin yaşayacak, bedenleri dirilecek. Ey sizler, toprak altında yatanlar, uyanın, ezgiler söyleyin. Çünkü senin çiyin sabah çiyine benzer, toprak ölülerini yaşama kavuşturacak.
} 


\begin{tabular}{ll}
\hline \multicolumn{2}{c}{ Von (uns) gegangen } \\
Zum ewigen Leben erwachen \\
\hline Toplam & 10
\end{tabular}

Tablo 5: Almancada Dini Motifli Örtmeceler

Buna göre Almanca ölüm ilanlarındaki Örtmecelerin yalnızca \%10'u dinî motifli, geri kalan \%90'i ise dinî motifli değildir. Almanca dinî motifli örtmecelerdeki ayıklama işlemi Türkçede de uygulandığında aşağıdaki tablo ortaya çıkmaktadır:

\begin{aligned} \hline Türkçe & \\ \hline Ebediyete intikal etmek & 1 \\ Ebedi istirahatgahına uğurlamak & 1 \\ Ebediyete uğurlamak & 1 \\ Hakkın rahmetine kavuşmak & 9 \\ \hline Toplam & 22\end{aligned}

Tablo 6: Türkçede Dinî Motifli Örtmeceler

Söz konusu verilere göre Türkçe ölüm ilanları azımsanmayacak derecede dinî motifli ifadeler içermektedir: Türkçe metinlerdeki dinî motifli örtmece oranı \%21 civarındadır. Oranın bu derece yüksek olmasına en büyük katkıyı sağlayan \%19 ile "Hakk'ın rahmetine kavuşmak" ifadesidir. Diğer örtmecelerin son derece düşük rakamlarda oldukları gözlemlenmektedir. Bu örtmecelerin temel dayanağını ölümden sonraki bir hayatın varlığına inanan düşünce oluşturmaktadır. Tıpkı Almanlarda olduğu gibi Türklerde de hem İslam öncesi, hem de İslam sonrası dönemde ahiret inancı son derece önemlidir. Ölüm "[...] Gerek eski Türk dinlerinde gerekse Türklerin mensubu bulundukları İslam dininde bir yok oluş olarak algılanmamış; ölümle her şeyin bitmediğine sadece bu dünyadan öbür dünyaya geçildiğine inanılmıştır." (Çıblak 2002: 606)

\subsection{Dinî Motifli Örtmecelerde Algı}

Dinî motifli örtmeceler geçerliliklerini milletlerin inanç sistemlerinden aldıklarından, yalnızca milletlerin değil, inanç sistemlerinin ölüm algısı hakkında da önemli veriler sunarlar. Türkçe ve Almanca metinlerdeki bu algılar Tablo 7 ve 8'de açıklanmıştır.

\begin{tabular}{|l|l|}
\hline $\begin{array}{l}\text { Dinî Motifli Örtmeceler } \\
\text { (Almanca) }\end{array}$ & Yarattığı Algı \\
\hline
\end{tabular}




\begin{tabular}{|l|c|}
\hline Heimgehen & $\begin{array}{r}\text { Kişinin gerçek evi ahirettir ve } \\
\text { herkes bir gün gerçek evine dönecektir. }\end{array}$ \\
\cline { 1 - 2 } $\begin{array}{l}\text { Voraus gehen } \\
\text { erwachen }\end{array}$ & $\begin{array}{r}\text { Dünya hayatı geçici, ahiret hayatı } \\
\text { sonsuzdur. }\end{array}$ \\
\cline { 1 - 1 } Im Himmel sein & $\begin{array}{r}\text { Ölen kişi kötü bir yere gitmez. } \\
\text { (Cennette gider) }\end{array}$ \\
\cline { 1 - 1 } $\begin{array}{l}\text { Von Christus gerufen } \\
\text { werden }\end{array}$ & $\begin{array}{r}\text { Ölen kişi dünyayı terk ederek } \\
\text { başka bir âleme göç eder. }\end{array}$ \\
\hline vie Welt/jemanden & \\
\hline Vorlassen (uns) gegangen & \\
\hline
\end{tabular}

Tablo 7: Almanca Dinî Motifli Örtmecelerde Algı

Almanca metinlerdeki dinî motifli örtmece sözler yarattıkları algı itibarı ile dört gruba ayırmak mümkündür. İlk grup (Heimgehen, Voraus gehen) ahireti kişinin gerçek evi olarak gören ve her canlının bir gün gerçek evine döneceğini(öleceğini) ima eden ifadelerden oluşmaktadır. İkinci grup (Zum ewigen Leben erwachen) diğer dünyadaki hayatın sonsuzluğuna vurgu yaparak ölümü yeni bir hayata doğuş şeklinde sunmaya çalışmaktadır. Üçüncü grupta (Im Himmel sein, Von Christus gerufen werden) ölen kişinin cennete gittiği algısının yaratılması hedeflenmektedir. Son grupta ise (Die Welt/jemanden verlassen, von (uns) gegangen) ölen kişinin yok olmadığı, başka bir âleme göç ettiği anlatılmak istenmektedir.

\begin{tabular}{|l|l|}
\hline $\begin{array}{l}\text { Dini Motifli Örtmeceler } \\
\text { (Türkçe) }\end{array}$ & \multicolumn{1}{c|}{ Yarattığı Algı } \\
\cline { 1 - 2 } Ebediyete intikal etmek & $\begin{array}{l}\text { Dünya fanidir, öbür dünya } \\
\text { ebedidir }\end{array}$ \\
\cline { 1 - 1 } Ebedi istirahatgahına uğurlamak & $\begin{array}{l}\text { Cennete gitmek (Tanrının rahmeti } \\
\text { cennet ile tecelli eder) }\end{array}$ \\
\hline Ebediyete uğurlamak & Hakkın rahmetine kavuşmak
\end{tabular}

Tablo 8: Türkçe Dini Motifli Örtmecelerde Algı

Türkçe ölüm ilanlarındaki dinî motifli örtmeceler yaratmaya çalıştıkları algı bakımından iki gruba ayrılmaktadır: Birinci grup (ebediyete intikal etmek, ebedi istirahatgahına uğurlamak, ebediyete uğurlamak) dünya hayatının faniliğine ve öbür dünyadaki hayatın ebediyetine dikkat çekmektedir. İkinci grup (Hakk'ın rahmetine kavuşmak) ise vefat eden şahsın cennete gittiğini (çünkü Tanrı'nın rahmeti cennet ile tecelli eder) dile getirmektedir. 
$\mathrm{Bu}$ verilerden hareketle Türkçe ve Almanca örtmeceler kıyaslandığında iki temel tez öne sürülebilir: Her iki dilde de tespit edilen dinî motifli örtmecelerin tamamının kaynağını milletlerin inanç sistemleri oluşturmaktadır. Her iki dilin dinî motifli örtmecelerinde de ölümün aslında yeni ve sonsuz bir hayatın başlangıcı olduğu veya ölünün kötü bir yere gitmediği algısı yaratılarak, ölümden duyulan üzüntünün teskin edilmesi amaçlanmaktadır.

\section{4. Örtmecelerin Sınıflandırılması}

Gazetelerin ölüm ilanlarındaki örtmeceleri farklı ölçütlere göre kategorize etmek mümkündür. Luchtenberg (1985: 99) ölümün algılanma biçimini esas alarak, ölümle ilgili örtmece sözleri beş ana başlık altında sınıflandırmaktadır: Bir kayıp olarak, uyku hâli olarak, seyahat olarak, yeni bir hayatın başlangıcı olarak ve veda olarak. Biz de aynı sınıflandırmaya sadık kalarak bir düzenleme yaptığımızda aşağıdaki Tablo 9 ve 10'daki dağılım ortaya çıkmaktadır.

\begin{tabular}{|c|c|c|c|}
\hline \multicolumn{4}{|c|}{ Almanca Örtmecelerin Sınıflandırılması } \\
\hline \multirow{3}{*}{ Kayıp olarak } & Trauern um jemanden & 35 & \multirow{3}{*}{49} \\
\hline & Versterben & 13 & \\
\hline & Das Leben verlassen & 1 & \\
\hline \multirow{5}{*}{ Seyahat olarak } & Voraus gehen & 1 & \multirow{5}{*}{8} \\
\hline & Heimgehen & 1 & \\
\hline & $\begin{array}{l}\text { Die Welt/jemanden } \\
\text { Verlassen }\end{array}$ & 4 & \\
\hline & $\begin{array}{l}\text { Von Christus gerufen } \\
\text { werden }\end{array}$ & 1 & \\
\hline & Von (uns) gegangen & 1 & \\
\hline Uyku hâli olarak & Daheim einschlafen & 2 & 2 \\
\hline Veda olarak & Abschied nehmen von & 37 & 37 \\
\hline \multirow[t]{3}{*}{$\begin{array}{l}\text { Yeni bir hayatın } \\
\text { başlangıcı olarak }\end{array}$} & $\begin{array}{l}\text { Zum ewigen Leben } \\
\text { erwachen }\end{array}$ & 1 & \multirow{3}{*}{4} \\
\hline & Im Himmel sein & 1 & \\
\hline & Im Herzen weiterleben & 2 & \\
\hline
\end{tabular}

Tablo 9: Almanca Örtmecelerin Sınıflandırılması

Ölümü bir kayıp olarak algılayan örtmecelerin \%49 ile en yüksek oranda olduğu görülmektedir. İkinci en yüksek oran ise \%37 ile ölümü bir veda olarak gören gruptadır. Ölümü bir seyahat olarak gören örtmeceler \%8 ile en yüksek üçüncü grubu 
oluşturmaktadır. Bunları \%4 ile yeni bir hayat algısı ve \%2 ile uyku algısı takip etmektedir.

\begin{tabular}{|c|c|c|c|}
\hline \multicolumn{4}{|c|}{ Türkçe Örtmecelerin Sınıflandırılması } \\
\hline \multirow{3}{*}{ Bir kayıp olarak } & Yitirmek & 1 & \multirow{3}{*}{76} \\
\hline & Vefat etmek & 30 & \\
\hline & Kaybetmek & 45 & \\
\hline \multirow{4}{*}{ Seyahat olarak } & Seyahate çıkmak & 1 & \multirow{4}{*}{4} \\
\hline & $\begin{array}{l}\text { Ebedi istirahatgahına } \\
\text { uğurlamak }\end{array}$ & 1 & \\
\hline & Ebediyete uğurlamak & 1 & \\
\hline & Ebediyete intikal etmek & 1 & \\
\hline Uyku hâli olarak & --- & - & - \\
\hline Yeni bir başlangıç olarak & Hakkın rahmetine kavuşmak & 19 & 19 \\
\hline Veda olarak & Aramızdan ayrılmak & 1 & 1 \\
\hline
\end{tabular}

Tablo 10: Türkçe Örtmecelerin Sınıflandırılması

Türkçe ölüm ilanlarında ölümü bir kayıp olarak algılayan örtmeceler \%76 ile en yüksek grubu teşkil etmektedir. İkinci en büyük grup ise \%19 ile ölümü yeni bir başlangıç şeklinde gören gruptadır. Ölümü bir seyahat olarak gören örtmeceler \%4 ile en yüksek üçüncü grubu, ölümü veda olarak görenler ise $\% 1$ ile en küçük grubu oluşturmaktadır.

a) Bir Kayıp olarak "ölüm"

Ölümü bir "kayıp" olarak gören örtmeceler gerek Almanca gerekse Türkçe ölüm ilanlarında en yüksek orana sahip grubu teşkil etmektedir. Türkçede kullanılan her dört örtmeceden üç tanesi (\%76), Almanca ilanların ise yarısı (\%49) bu gruba aittir. İlgili grubun diğerlerinden en önemli farkı, ölüm olgusunu, ölen kişinin geride kalan yakınları açısından ele alan örtmeceleri de barındırmasıdır.

b) Bir seyahat olarak "ölüm"

$\mathrm{Bu}$ gruba ait örtmeceler her iki dilde de oldukça az kullanılmıştır. Almanca ilanlarda oran $\% 8$ iken, Türkçe ilanlarda bu oran \%4'tür. Pagan dinlerden semavi dinlere kadar birçok inanç sisteminin ölümden sonra başka bir hayatın varlığına inandıkları bilinmektedir. Bu gruptaki örtmeceler de insanların öldükten sonra başka bir âlemde yaşamaya devam edecekleri inancından kaynaklanır. Ölümün aslında bir yok oluş değil, başka bir âemde yaşamaya devam etmek için çıkılan yolculuğun başlangıcı olduğu mesajını vermeye çalışır.

c) Bir uyku hâli olarak "ölüm" 
Hem Almanca hem de Türkçe ilanlardaki en küçük grubu oluşturmaktadır. Almanca ilanlarında yer alan örtmecelerin yalnızca \%2'si bu gruba dâhildir. Ölümün "uyku hâli" olarak algılanması durumu Türk kültüründe de bulunmasına (Sağol Yüksekkaya 2010: 27-34) rağmen, bu duruma gönderim de bulunan hiçbir örtmece, Türkçe ilanlarda kullanılmamıştır.

d) Yeni bir hayatın başlangıcı olarak "ölüm"

Ölüm her ne kadar fiziksel bakımdan bir yok oluşu ifade etse de, gerek İslam, gerekse Hristiyanlık inancında mutlak bir yok oluş değildir, hayatın başka bir boyutta devam etmesidir. Bu inanışa gönderme yapan örtmecelerin oranı Almanca ilanlarında yalnızca \%4'tür. Türkçede ise bu oran \%19'a yükselmektedir. "Cennet, sonsuzluk, rahmet" gibi kavramlarla ölüm adeta özenilmesi gereken bir olgu şeklinde sunulmaktadır. Türk metinlerinde şekil değiştirme (Yeşil 2015) aracı olarak da görülür.

e) Bir veda olarak "ölüm"

Ölümün vuku bulması ile artık geri döndürülmesi mümkün olmayan bir süreç başlamıştır. Ölen kişi ile bir daha birlikte olunabilmesi söz konusu olmadığından, ölünün cenaze töreni aslında aynı zamanda bir vedalaşmadır. Ölümü "veda" olarak gören Almanca örtmeceler \%37 gibi oldukça yüksek bir orana sahiptir. Türkçe örtmecelerde ise bu gruba dâhil edilebilecek bir örtmece mevcut değildir.

Türkçe ve Almanca ölüm ilanları birlikte incelendiğinde çeşitli benzerlikler ve farklılıklar göze çarpmaktadır. Öncelikle benzeşen yönler üzerinden gidersek; her iki dilde de ölümü bir "kayıp" olarak algılama hâlinin son derece yüksek olduğu ve ilk sırada geldiği gözlemlenmektedir. Yine aynı şekilde "seyahat" olarak görme eğiliminin her iki dilde de oldukça düşük oranlarda yer aldığı görülmektedir. Ölümü "veda" şeklinde yorumlayan örtmecelerin oranı Almancada \%37 iken, Türkçede bu oran \%1'dir. Aynı fark "yeni bir başlangıç" algısı yaratmayı hedefleyen örtmecelerde de mevcuttur. Türkçedeki her beş örtmeceden biri bu algıyı esas edinirken, Almancadaki oran yalnızca \%4'tür. Dikkat çeken bir diğer nokta ise Türkçe ilanlarda ölümü bir "uyku hâli” şeklinde gören örtmecenin bulunmamasıdır.

\section{5. Örtmece Kullanımında Yaşanan Değişim}

Çalışmanın bu bölümünde 2000 yılında yapılan benzer bir çalışmanın ${ }^{8}$ verilerinden faydalanılarak aradan geçen 17 yıllık zaman dilimi içerisinde gazete ilanlarındaki örtmece kullanımında yaşanan değişimlerin tespit edilebilmesi amacıyla Tablo 11 ve 12 hazırlanmıştır:

\begin{tabular}{lll}
\hline & 2000 & 2017 \\
\hline Hakkın & 16 & 19 \\
Kaybetmek & 27 & 45 \\
Vefat etmek & 42 & 30 \\
\hline
\end{tabular}

\footnotetext{
${ }^{8}$ Ersan YÜKSEL'in "Euphemismus in der Alltagsssprache und in den Alltagsprachen der Politik" adlı doktora tezi.
} 


$\begin{array}{ccc}\text { Toplam } & 85 & 94 \\ \text { Tablo 11: Türkçe Örtmecelerin Kullanım Sıklığında Değişim (\%) }\end{array}$

Tablo 11'e göre: 2000 yılında en çok kullanılan üç örtmece toplam örtmecelerin \%85'ini teşkil etmektedir. 2017 yılında geldiğinde ise bu oran \%94'e yükselmiştir. Bu verileri esas alarak Türkçe ölüm ilanlarında çeşitliliğin gitgide azaldığı ve tek tipleşme eğilimin artarak devam ettiği söylenebilir. Bu örtmeceleri yarattıkları algı itibarı ile ele alırsak ölümün yeni bir başlangıç olduğunu vurgulayan örtmecelerin oranında \%3'lük bir artış yaşanmıştır. Ölümü bir kayıp olarak gören örtmecelerde ise \%6'ık bir artış söz konusudur. Özetle Türkçe ölüm ilanlarının yaratmış olduğu algılarda çok büyük bir değişim görülmemektedir.

\begin{tabular}{lrc}
\hline & 2000 & 2017 \\
\hline Abschied nehmen von & 26 & 37 \\
Trauern um jemanden & 0 & 35 \\
Versterben & 35 & 13 \\
Entschlafen & 18 & 0
\end{tabular}

Toplam $\quad 8 \quad 85$

Tablo 12: Almanca Örtmecelerin Kullanım sıklığında değişim (\%)

Almancaya bakıldığında, Türkçedeki tek tipleşme eğiliminin burada da mevcut olduğu gözlemlenmektedir. 2000 yılında \%78 olan söz konusu oran, 2017'ye gelindiğinde \%85'e yükselerek büyük bir artış göstermiştir. Almanca ölüm ilanlarında Türkçedekine kıyasla büyük değişiklikler yaşanmıştır. 2000 yılında $\% 18$ olan "entschlafen"(ebedi uykuya dalmak) ifadesi 2017'de hiç kullanılmamıştır. Bir başka çarpıcı değişim ise "trauern um jemanden" (birinin yasını tutmak) örtmecesinde yaşanmaktadır. 2000 yılındaki çalışmada kendine hiç yer bulamayan (ya da diğerleri altında sınıflandırılmış olan) söz konusu ifade, 2017 yılında \%35 gibi büyük bir orana kavuşmuştur.

Yarattıkları algı itibarı ile incelendiğinde veda algısı yaratan örtmeceler \%11'lik bir artış, kayıp algısı yaratanlar ise \%13'lik bir artış göstermiştir. Ölümü bir uyku hâli olduğuna vurgu yapan örtmecelerde ise \%18'lük bir azalma dikkat çekmektedir. Sonuç olarak her iki dilde de çeşitliliğin azalma eğiliminde olduğu ve ağırlığın üç ana örtmece üzerinde toplandığı dikkat çekmektedir. Yaratılan algı açısından bakıldığında Türkçe örtmecelerde çok belirgin bir değişim görülmemektedir. Almancada ise "veda" ve "kayıp algısı" yaratan örtmecelerde artış görülürken, ölümü "uyku hâli” olarak gören ilanlarda azalma söz konusudur. 


\section{Sonuç}

Örtmeceler dile ifade zenginliği katan ve güzelleştiren unsurlardır. Fakat asıl önemli katkılarını iki temel alanda sağlarlar: Birincisi, örtmece kelimeler, dilsel tabuların oluşumuna neden olan nesneleri, olayları ya da düşünceleri ifade eden kavramların, başka bir forma bürünerek dildeki varlıklarını devam ettirebilmelerinde büyük rol oynarlar. İkincisi ise, Örtmece ifadelerin sağlamış olduğu imkânlar sayesinde, tabu kelimelerin kullanılmamasından dolayı yaşanması muhtemel iletişim aksaklıklarının önüne geçilir. Ölümün geride kalanlar için büyük bir elem, ölen için ise istenmeyen ve korkulan bir hadise olması, bu alanda çok sayıda örtmece ifade kullanılmasına yol açmıştır. Türkçe ve Almanca Gazetelerin ölüm ilanlarındaki örtmeceler ve bunların içerdikleri ölüm algısının incelenmesi hedefleyen bu çalışmada şu bulgular elde edilmiştir:

Her iki dilde örtmece kullanma eğiliminin son derece yüksek olduğu saptanmıştır. Türkçe ilanların neredeyse tamamında (\%96) örtmece kullanılırken, Almanca her dört metinden üçünde örtmece kullanılmaktadır. On üç farklı örtmeceye yer veren Almanca metinler, çeşitlilik bakımından, dokuz farklı örtmece kullanılan Türkçe metinlere kıyasla daha zengindir. Elde edilen bir başka bulgu ise, hem Almanca hem de Türkçede tüzel kişiliklerin özel şahıslara göre çok daha fazla örtmece kullanıyor oluşlarıdır. Türk tüzel kişiliklerin ilanlarının tamamında, Alman tüzel kişiliklerinin ise neredeyse tamamında örtmece kullanılmaktadır.

Her iki dilde kullanılan örtmecelerde en belirgin algı, ölümün bir "kayıp" olarak görülmesidir. Almancadaki her iki örtmeceden bir tanesi, Türkçede ise örtmecelerin dörtte üçü ölümü bir "kayıp" olarak algılamaktadır. "yasını tutmak, vefat etmek, veda etmek, yitirmek, kaybetmek" gibi kelimeler teknik olarak örtmece tarifine sorunsuzca uyarlar. Fakat bu kelimelerle pozitif bir algının yaratıldığından söz edilemez. Olsa olsa en fazla nötr bir algı meydana getirilmiş olur. Oysa içinde "cennet, rahmet, ebediyet" gibi kavramları barındıran örtmecelerde durum çok farklıdır. Dolaysıyla ölümü bir "kayıp" olarak algılayan örtmeceler, ölüme aynı zamanda olumsuz bir anlamda yüklemiş olurlar. Almancada ikinci ağır basan algı ise vedadır. İnsanın sevdiklerine veda etmesini de olumsuz olarak değerlendirirsek, Almanca metinlerdeki örtmecelerin \%86'sının ölümü olumsuz bir hadise olarak ele aldıklarını söylemek mümkündür. Buradan hareketle hem Türkçe, hem de Almanca metinlerde ölümün çok büyük ölçüde olumsuz bir vaka olarak algılandığı söylenebilir.

İnanç sistemlerinin yansıması açısından ele alındığında, Türkçede Almancaya göre iki kat daha fazla dinî motifli örtmece kullanıldığı görülmüştür. Ölüm ilanlarında dinî motifli örtmeceler, dinî motifli olmayanlara göre çok daha az tercih edilmektedir. Her iki dilin dinî motifli örtmecelerinde de "ebedî hayat" ve "cennet" vurgusu dikkat çekmektedir.

2000 yılında yapılan benzer bir çalışma ile karşılaştırıldığında, her iki dilin ilanlarında da ağırığın belli ifadelerin üzerinde toplandığı ve bariz bir tek tipleşme eğiliminin ortaya çıktığı görülmektedir. Bazı ifadelerin kullanım oranları artarken, bazılarınınki azalmakta ya da tamamen ortadan kalkmaktadır. Kullanılmayan 
kelimelerin toplum hafızasında unutulma sürecine girdiğini göz önünde bulundurursak, bunun hem örtmecelerdeki ifade çeşitliliğinin azalması, hem de kelime hazinesinde daralma gibi bir sonuca yol açma intimali göz ardı edilmemelidir. Bununla birlikte her iki dilde de ölümü bir "veda" veya "kayıp" olarak sunan örtmecelerin sayısında bir artış söz konusudur. Almanca metinlerde son derece belirgin olan bu artış, Türkçede daha az belirgindir.

\section{KAYNAKÇA}

AKBAŞ, Muhsin, (2002), "Yahudi ve Hıristiyan Düşüncesinde Ölüm Sonrası Hayat ve Diriliş İnancının Dini ve Teolojik Temelleri”, D.E.Ü. İlahiyat Fakültesi Dergisi, 15: 3760.

AKSAN, Doğan, (2009), Her Yönüyle Dil, III. Cilt, Ankara: Türk Dil Kurumu.

BILGINER, Hayriye, (2001), "Batı Dillerinde ve Türkçede güzel Adlandırmalar", Türk Dili, 598: 441-445.

BRAUN, Hans-Jürg, (1996), Das Jenseits. Die Vorstellung der Menschheit über das Leben nach dem Tod, Zürih: Artemis \& Winkler Verlag.

ÇIBLAK, Nilgün, (2002), "Anadolu'da Ölüm Sonrası Mezarlıklar Çevresinde Oluşan İnanç ve Pratikler", Türk Kültürü, 474: 605-614.

DEMIRCi, Kerim, (2008), “Örtmece (Euphemism) Kavramı Üzerine”. Milli Folklor, 77: 21-34.

DUDEN, (1996), Universalwörterbuch des Deutschen, Manheim/Leipzig/Viyana/Zürih: Dudenverlag.

DURMUŞ, Mustafa, (2012), "Ölümü Güzelleştiren Eda: Türkçe Şair Tezkireleri İle Şairnâmelerde Ölüme Bakış ve Ölümün İfade Biçimleri Üzerine”, Milli Folklor, 94: 105122.

GAZETE TIRAJLARI, (2017), Gazetelerin Haftalık satış Raporu, http://www.gazetetirajlari.com/HaftalikTirajlar.aspx. (05.11.2017)

GÜNGÖR, Ahmet, (2006), “Tabu-Örtmece (Euphemism) Sözler Üzerine”, A.Ü. Türkiyat Araştırmaları Enstitüsü Dergisi, 29: 69-93.

INCIL. https://www.bibleserver.com/start. (25 Aralık 2017).

LUCHTENBERG, Sigrid, (1985), Euphemismen im heutigen Deutsch. Mit einem Beitrag zu Deutsch als Fremdsprache, Frankfurt am Main: Peter Lang

MAIER, Bernhard, (2001), Die Religion der Kelten: Götter, Mythen, Weltbild, Münih: C.H. Beck.

MEVLEVI, Tahirül, (1984), Edebiyat Lügatı, İstanbul: Enderun Kitabevi.

RAMMSTEDT, Otthein, (1964), “Tabus und Massendmedien”, Publizistik, 9: 40-44. 
SAĞOL-YÜKSEKKAYA, Gülden, (2010), “Türklerde Ölümün Algılanışı "Ölmek” Karşılığı Kullanılan Kelimelerden Hareketle”, Uçmağa Varmak Kitabı, (Ed. E. GürsoyNaskali, G. Sağol-Yüksekkaya), İstanbul: Kitabevi, 3-40

SCHRÖDER, Hartmut. "Der Tabu-Komplex - Kultursemiotische Überlegungen" (19.11.2013) https://jelinektabu.univie.ac.at/tabu/forschungsfeld-tabu/hartmutschroeder/. (11.01.2018).

STATISTA, (2017), Verkaufte Auflage der Süddeutschen Zeitung vom 4. Quartal 2010 bis zum 1. Quartal 2018.

https://de.statista.com/statistik/daten/studie/382110/umfrage/auflage-dersueddeutschen-zeitung/. (05.11.2017)

TÜRCKE, Christoph, (1994), “Tabu”, Die Zeit, Nr. 36, 2. September 1994.

TDK. Türkçe sözlük. http://www.tdk.gov.tr/index.php?option=com_bts. (05.11.2017).

TÜRKMEN, Seyfullah, (2009), "Türkçedeki Örtmece Sözler", Karadeniz Araştırmaları, $\mathrm{XI}, 23: 131-140$

ÜSTÜNER, Ahat, (2009), “Örtmece Sözlerle İlgili Terimler”, Turkish Studies, 4/8: 166176.

VON WILPERT, Gero, (1989), Sachwörterbuch der Literatur, Stuttgart: Alfred Kröner Verlag.

YEŞiL, Yılmaz, (2014), Türk Dünyasında Geçiş Dönemi Ritüelleri, Ankara, Grafiker Yayınları.

YEŞil,, Yılmaz, (2015), Türk Sözlü Anlatılarında Şekil Değiştirme, Ankara, KalemKitap Yayınları.

YÜKSEL, Ersan, (2000), Euphemismus in der Alltagssprache und in den Fachsprachen der Politik, der Internationalen Beziehungen und des Gesundheitswesens im Deutschen und Türkischen, Yayınlanmamış Doktora Tezi, Hacettepe Üniversitesi Sosyal Bilimler Enstitüsü, Ankara.

ZÖLLNER, Nicole, (1997), Der Euphemismus im alltäglichen und politischen Sprachgebrauch des Englischen, Frankfurt am Main: Peter Lang. 